\title{
Lampung Krakatau Festival: Tourism Development and Active Citizens Participation to Strengthen Community Civic Virtue
}

Indonesian Journal of Tourism and Leisure, 2021
Vol. 02 (2), 62-75
(c) The Journal, 2021
DOI: $10.36256 /$ ijtl.v2i2.130
https://journal.lasigo.org/index.php/IJTL
Article History
Received: April $5^{\text {th }}, 2021$
Revised: June $7^{\text {th }}, 2021$
Accepted: June $21^{s t}, 2021$

Muhammad Mona Adha

Department of Civic Education, Teacher Training and Education Faculty, Universitas Lampung mohammad.monaadha@fkip.unila.ac.id

Dasim Budimansyah

Department of Civic Education, Social Sciences and Education Faculty, Universitas Pendidikan Indonesia budimansyah@upi.edu

\section{Arief Nugroho}

The Ministry of Tourism and Creative Economy, Lampung Province etanug@yahoo.co.id

\section{Mitchell Mollison}

Performing Arts, Monash University

greenearth482@gmail.com

\begin{abstract}
The tourism sector must be able to involve the community through space in order to gather, interact and communicate. Krakatau Festival as a medium that involves the participation of individuals and the community can support the development of tourism in Lampung Province. The community engagement in the festival is responsible as citizens of the community including the government, stakeholders, people, communities to take part actively and create strong social interrelation and cohesion. Tourism development through the community as part of sapta pesona is the main focus supported by a variety of cultural activities, destinations, and ultimately creates social cohesion as part of the civilization of citizenship. Qualitative research with ethnographic methods is implemented to get data and information comprehensively from various sources. The results of the study found that the context of the Krakatau Festival activities in real terms has the potential to increase tourism with historical values of Krakatau and can unite the community in a positive social interaction relationship and strengthen the active participation of local community virtue.
\end{abstract}

Keywords: Participation; Civic Virtue; Community; Lampung Krakatau Festival; Tourism.

\section{Introduction}

A festival with a cultural approach is a way to support cultural intergenerational continuity and in-group community values and aesthetics (Sommers, 1996; Van Zyl and Botha, 2004; Fahm,

Corresponding Author

Name : Muhammad Mona Adha

Email : mohammad.monaadha@fkip.unila.ac.id 
2015; Kyle \& Kayode, 2015). The Krakatau Festival is the biggest cultural event in Lampung Province which has involved the people of Lampung as tourism development and brings messages of cultural values. Cultural festivals contain a very broad cultural diversity and are closely related to the life of local communities (Gibson et al., 2010). The Krakatau Festival is one of the media to involve local community participation to be directly involved.

Cultural life and culture in Indonesian society are soul that attached and applied in everyday life. The cultures have energized and implemented. It is not only as own identities as carriers for their respective cultures, but also have an impact on the development and strengthening of social interaction in the wider community (Frost, 2016). Festival is one of the media to strengthen the social cohesion of community members. The Krakatau Festival is a moment of opportunity for societies and communities to take part. Thus, the government, Lampung Provincial Tourism Office, is trying to develop ways to get the Lampung people involved in the festival.

Lampung Province has a diversity of cultural backgrounds from various cultural backgrounds from various ethnic groups who have lived side by side in the daily activities of the people of Lampung. Bringing people together requires a medium, event, or space so that all components of society from various cultural backgrounds (Lei and Zhao, 2012) interact to create social harmony (Adha, 2015).

Civic engagement gives confidence to stakeholders, people, institutions, communities that through civic engagement will offer a sense of responsibility as citizens to build an environment. Therefore, the awareness of each needs to realize that we are living in a wider (global) area by participating in various experiences which also of course lead to activities that provide knowledge in preparing ourselves for the life of a global society. By looking at the concept of civic engagement, it is no longer only limited to local life, but civic engagement wants every person involved locally, nationally, and globally. Mature society can affiliate to fulfill its social needs by reflecting itself as a responsible citizen, requiring the growth of free and equal relationships, growing of solidarity in everyday social cohesion. Citizen involvement is a means to develop selfcapacity, foster a sense of tolerance for others, build communities, support activities, and develop common goals. Engagement in a diverse community environment requires not only knowledge and skills, but also values and motivations, and commitment in the community environment through social interrelation or social cohesion that creates social harmonization. Therefore, the expected result for each person's personal and social responsibility is the knowledge of citizens and how citizens carry it out in local and global areas and together with intercultural knowledge, competencies by citizens, values/ethics, principles personal basis, and other skills as a provision for continuous learning.

\section{Literature Review}

The Krakatau Festival has been well-known by the people of Lampung and has become one of Indonesia's 100 Calendar Events (Kemenpar, 2018). The Krakatau Festival is included in the event calendar as an opportunity for organizers and the community to jointly succeed in the event to attract local, national, and international participation. In 2017, Krakatau Festival was in the 27 th and as one of the oldest festivals in Indonesia. In general, festivals have a positive impact on local communities in terms of local economic income (Gursoy \& Rutherford, 2004; Pizam \& Milman, 1986), and community interactions (Gursoy et al., 2002; Gursoy \& Rutherford, 2004; Lankford, 1994).

The Krakatau Festival has been held since 1990 to promote tourism and build emotional attachment and community participation. The XXVII Krakatau Festival was held on August 25272017 and has succeeded in bringing in 30,000 visitors during the three days of implementation. The festival presents a series of activities that participated in by government agencies, district delegations, schools, communities, and stakeholders (Meiliyana et al., 2020). Activities carried out include: cooking demonstrations, traditional games, handicrafts, a traditional Lampung 
clothing bazaar, Tapis weaving, fashion shows, music concerts, and traditional dances. One of the biggest events involving the participation of residents is the Cultural Parade: Lampung Culture and Tapis Carnival. Thousands of people watched the parade displaying the cultural richness and local wisdom of the Lampung people.

Festival is a means for every person and society to come together and interact positively (Frost, 2016). The Krakatau Festival can offer understanding as well as experience for the community to interact together amidst the diversity of cultures and each background. The festival can educate community members to cooperate, respect, appreciate, foster shared responsibility, and are aware of being part of society. Social harmony can be realized. The value of togetherness of the community in the festival is related to the civility of citizenship. Everyone can show public interests in order to take part, support, and help the festival implementation. Thus, individuals show interests appropriately to carry out the interests of the public or society.

Festivals play an important role in increasing the competitiveness and sustainability of a goal by increasing understanding of identities and providing opportunities to learn about cultural heritage (Pardy, 1991; Kim et al., 2016; Johansson and Toraldo, 2015), "the curated program is that festival-goers could develop both a sense of the national cultures and histories depicted" (Bruveris, 2015, p. 220; Johansson and Toraldo, 2015; Everett \& Parakoottathil, 2016). The main characteristic of a festival is an engagement of a community group, where they can interact and access the festival freely in which there are media such as arts and crafts, performances and demonstrations (Arcodia \& Whithford, 2006; Muller \& Pettersson, 2006). Various activities in the festival carried out in time and space and have a stronger national place (Einarsen \& Mykletun, 2009). Thus, people understand more about the festival, and take advantage of the moment through their participation.

\section{Method}

This study uses a qualitative research design with the intention that researchers are more flexible in examining and analyzing various phenomena in the field comprehensively, as explained by Creswell (2008) that qualitative data can be followed and understood the flow of events chronologically, assessing the causation in the scope of the minds of the local people and obtained many useful explanations.

Qualitative research by using ethnographic approach was carried out to find a link between the cultural activities of the Krakatau Festival and the active participation of the community to support the tourism sector. Ethnographic approach is very proper to be implemented by observing and participating directly with respondents and the activities carried out during the preparation period of the Krakatau Festival implementation. Researchers participated in the implementation of the Krakatau Festival in year of 2016 and 2017 to get information and supporting data from the organizing committee, festival participants, stakeholders, volunteers, and visitors.

Observations were conducted before the festival. Observations provide the first information for researchers to design and find the next stages. Researchers conducted observations on the preparations time. Observations included the participated parties. Data collection through interviews conducted on 16 respondents. Each interview conducted for 60 minutes for each respondent in separate places. Interviews were conducted with natural conversations and focused on research questions that had been prepared based on three main components, namely: (1) The involvement of people and communities in the tourism sector; (2) Forms of participation in the Krakatau Festival; (3) experience from the Krakatau Festival. Triangulation is used for data analysis techniques. Researchers processed data and information based on the results of 
observations, interviews, and documentation analysis. Thus, data analysis produces descriptions supported by theories that are directly related to research indicators.

\section{Results}

\subsection{Lampung Tourism Development through the Lampung Krakatau Festival}

National tourism activities under the Minister of Tourism by Soesilo Soedarman in 1990, each province began to intensify the festival as a tourist attraction in Indonesia. The study was conducted for about four years before 1990 by Aburi Daud and Idrus Djaendar Muda on finding and establishing the right icon as the main activity in Lampung Province, namely Krakatau. Thus, Krakatau was an icon of the festival which has since been called the Krakatau Festival since 1990.

In order to introducing and developing Lampung province tourism, it has slogan as Lampung the Treasure of Sumatra to support Sapta Pesona in the millennial era. Lampung as the gateway on the island of Sumatra has a uniqueness and infrastructure that supports the attraction of tourists to visit. Both of the provincial government and the Lampung Provincial Tourism continues to develop advance tourism destination sector and carry out cultural activities through the Krakatau Festival. In principle, tourism products provided with good quality and strong criteria, so that people interested in coming (Wibowo, 2018; Supriono, 2017). Developing the Krakatau Festival and passing on the historical values can strengthen the "sense of belonging" to Krakatau and its culture.

Table 1. Synergy of government, society and individuals

\begin{tabular}{lll}
\hline Involvement & Media & Implementation \\
\hline Government & $\begin{array}{l}\text { Inviting active participation of community } \\
\text { members through delegates involvement, }\end{array}$ & $\begin{array}{l}\text { Organizing the Krakatau Festival and similar } \\
\text { activities to strengthen social cohesion }\end{array}$ \\
schools, communities, and stakeholders & \\
Society & $\begin{array}{l}\text { Participate and get involved: starting from Showcasing cultural attractions, committees, } \\
\text { the planning, preparation, and bazaars (handicrafts, food, clothing), } \\
\text { implementation stages of the festival. }\end{array}$ \\
& $\begin{array}{l}\text { Participate in festival activities to increase } \\
\text { knowledge, skills, information, and networks } \\
\text { (people to people) }\end{array}$ & $\begin{array}{l}\text { Visitors, volunteers, performing arts, traditional } \\
\text { leaders, community leaders, researchers, sources }\end{array}$
\end{tabular}

Source: (the results of data processing, 2018)

Based on table 1, for the successful implementation of the Krakatau Festival as one of the tourism events in Bandar Lampung city, it is necessary to collaborate with the government, society, and people. The government is in charge of providing the event's organization, then the community participates in helping the process from preparation to implementation, and people actively participate individually through volunteering, as well as other positive roles. Through the synergy with strong dedication, the Krakatau Festival agenda carried out well every year to strengthen Pesona Indonesia.

The Krakatau Festival format is prepared by taking into account things that have a broad impact on tourism in the future. Planning is very important by taking into account the impact on society. The community is an inseparable part of the progress of the tourism sector because society is the largest part that can have a direct influence on tourism objects and events. The Krakatau Festival organizing committee maximally thinks strategically and works practically by involving work units, stakeholders, business actors, and community groups to support the annual festival. Basically, the essence of traveling is to encourage people to visit and are particularly interested in coming to Lampung, especially tourists from outside Lampung. 
The Krakatau Festival is one of the leading cultural activities from Lampung Province which has been held annually since 1990 which brings out the richness of culture and traditions. This festival is a promotion of the tourism potential of each district/city by carrying out carnival activities, traditional art attractions, exhibitions, and various competitions. Thus, the Krakatau Festival implementation has experienced many variations of activities, both improvements, and changes at each event.

\subsection{Lampung Community Active Participation in the Lampung Krakatau Festival}

Festival is a medium to interact from various backgrounds. The community as citizens are actively participated and have responsible (Lei \& Zhao, 2012; Persada, 2011) in activities both small and large as an effort to create and strengthen cohesion between citizens (Rao, 2001; Supriyono \& Adha, 2020). Cultural festivals in particular can be used as a space for the expression of all components of society to increase awareness in cultural preservation so that it can survive and be passed on to the next generation (Sommers, 1996). Therefore, the government needs to help the festivals implementation, festival locations, and publications to the public in local, national and international. Citizen interaction is strengthening the relationship between people and society (Long and Perdue 1990; Rao 2001) as an urban community (Stone, 2001) in cultural meetings, and it is the duty of people to keep culture as members of society (Sandu, 2015).

This study explains whether festivals can be a medium for personal participation to strengthen the social cohesion of citizens in the modern era like today. Ideally, the festival is able to become a space for the community to contribute. It must be realized that the festival has enormous benefits for increasing individual skills, public knowledge, and as a space for social interaction which is increasingly needed today. Families, adolescents, adults, children, and all social strata can meet in one festival place. Thus, they get to know the environment better and improve a local community identity (Felsenstein \& Fleischer, 2003; Formica \& Uysal, 1998; Van. Der Wagen \& Carlos, 2005).

After going through a long study process for four years, the icon of Mount Krakatau used to become the name of a cultural event, the Krakatau Festival. Based on the results of the study, it was then taken into consideration to set up and carry out the Krakatau Festival in 1990. The Krakatau icon implemented for increasing tourism in Lampung, attracting visitors, and involving wider community participation. Since the first time of this festival, it has involved the community not only in the city center but also involving coastal communities which are directly next to Mount Krakatau (Tour Krakatau).

Table 2. The positive value of government, community and individual involvement

\begin{tabular}{lll}
\hline Involvement & Internal & External \\
\hline Government & $\begin{array}{l}\text { Increase cooperation; Get community } \\
\text { support; Development based on evaluation }\end{array}$ & $\begin{array}{l}\text { Increase community awareness and involvement; } \\
\text { Continuous program }\end{array}$ \\
Society & $\begin{array}{l}\text { Increase participation/cooperation; } \\
\text { Responsive to activities; Increase public } \\
\text { knowledge; Expand information }\end{array}$ & $\begin{array}{l}\text { Sisdom; Fostering a spirit of solidarity; Creating } \\
\text { social justice }\end{array}$ \\
Individuals & $\begin{array}{l}\text { Increase the attitude of responsibility; } \\
\text { Increase the sense of caring; Increase } \\
\text { knowledge and skills }\end{array}$ & $\begin{array}{l}\text { cooperative groups; Transfer of knowledge / } \\
\text { experience; Information dissemination }\end{array}$
\end{tabular}

Source: (the results of data processing, 2018)

Based on table 2, the Krakatau Festival implementation is multi-aspect and multi-regional, and in a work together between one party and another. Large community involvement is the 
main thing as a form of strengthening social cohesion. A Festival is a medium that is a place for people to meet, interact and communicate from various backgrounds. Individuals as part of society/citizens have responsible to take part by activating most positive collaboration.

The Krakatau Festival implementation is a multiplier, multi-regional and the main initiator of the Krakatau Festival. The main contributor of the festival is the government by involving the community, stakeholders, and cultural groups in Lampung Province. In general, all events in the Krakatau Festival are still guided by the values of the Lampung tradition, the habits or customs of the community, by promoting solidarity and togetherness. The festival is an attraction and requires solid collaboration to fulfill the goals and targets.

Active participant is a responsible person, able to act intelligently in social activities, and continuously able to develop social skills, citizenship competencies or improve social skills, and citizenship competencies so that they can become a person who has good character (Best in Budimansyah \& Suryadi, 2008). Citizens' civility in the context of behavior (civic virtue behavior) is based on good relations between fellow humans and the greatest achievement satisfaction which are marked by the emergence of attitudes or behaviors. Citizens' civility is more awake due to what expected and fulfilled by paying attention to the balance between rights and obligations. The civility by everyone will offer a sense of security and comfort for the surrounding environment (Chambel \& Alcover, 2011).

\subsection{The role of individuals and community members in strengthening civic virtue through the Lampung Krakatau festival}

A festival activity requires support and active participation from the community (Hixson, 2014; Lee et.al, 2016). Therefore, "civic engagement" is the main thing in building a good social life (Matheson and Tinsley, 2016; Arcodia \& Whitford, 2006). Based on research conducted at three universities in the United States, Doolittle \& Faul (2013) revealed that to involve each individual, people and communities given the confidence that they are capable of carrying out tasks or activities related to building communities, regardless of age, gender, and race. The closeness between community members and good public open spaces is a form of social interaction that has run according to the public open space function itself. The emotional bonds of community members are also important in planning public open spaces development. It must reflect its historical roots, so that public space functions beneficial for artists to have space for contemplation. Thus, urban residents who are still elderly can still reminisce so that newcomers also have space and interaction with city residents (Persada, 2011).

Designing a festival that can bring a large number of community members to come together is very important because the community and resident participation is a support for the success of a festival activity (Lei \& Zhao, 2012). Festival as a "social event" is able to build strong relationships among fellow citizens (social cohesion), groups, and communities to keep culture, communicate, interact, work together, and see new things or developments. The festival indeed is very synonymous with the concept of a celebration so that citizens can take advantage of the opportunity to celebrate through the festival to get to know one another from one culture to another, know each other about various forms of cooperation in an interesting way and offer benefits in strengthening social relations between them.

Festivals are more about developing social relationships, both between organizers and visitors, and interaction between visitors (Johansson \& Toraldo 2015). The social relationship in question is to produce a study of aesthetic experience development by prioritizing personal involvement and conveying the festival's message content to the community precisely. Festival is a strategy to increase individual participation, social obligation actively involved in the community, offer personal and collective pride, and increase self-confidence (Roemer, 2010).

The people of Lampung Province have various backgrounds, especially when the transmigration program implemented, many people came from Java, Madura, and Bali in the 
1930s, then transmigration carried out again in the 1970s and 1980s under President Soeharto (Chris, 2003). Therefore, the Krakatau Festival is an important moment to unite people in the public space so that they can interact with each other which can strengthen "social capital". Communities are the basic forces that are a part of the festival itself, they are not objects, they are the subjects or actors, the owners, and preservers of the culture. Society controls the preparation, and the government only supports and facilitates it. On the other hand, community involvement is required in community-based tourism development (Persada, 2011).

Table 3. Individuals and Community Involvement

\begin{tabular}{|c|c|c|c|c|c|}
\hline Level & Take Part & Ability & $\begin{array}{ll}\text { Forms } & \text { of } \\
\text { Engagement }\end{array}$ & $\begin{array}{l}\text { Internal } \\
\text { benefits }\end{array}$ & $\begin{array}{l}\text { External } \\
\text { benefits }\end{array}$ \\
\hline Individual & $\begin{array}{l}\text { Visitors; } \\
\text { Volunteer; } \\
\text { Students; } \\
\text { College student; } \\
\text { Researcher }\end{array}$ & $\begin{array}{l}\text { Knowledge; } \\
\text { Practical ability; } \\
\text { Experience }\end{array}$ & $\begin{array}{l}\text { Participation; } \\
\text { Coordination; } \\
\text { Technical and non- } \\
\text { technical; } \\
\text { Interests or abilities }\end{array}$ & $\begin{array}{l}\text { Experience; } \\
\text { Knowledge; } \\
\text { Information; } \\
\text { Cooperation; } \\
\text { Strategy; } \\
\text { Discipline }\end{array}$ & $\begin{array}{l}\text { Share experiences } \\
\& \text { information; } \\
\text { Community; } \\
\text { Trust }\end{array}$ \\
\hline Society & $\begin{array}{l}\text { Agency; } \\
\text { Delegation; } \\
\text { Organization; } \\
\text { Community } \\
\text { groups; } \\
\text { respected person; }\end{array}$ & $\begin{array}{l}\text { Cooperation } \\
\text { program; } \\
\text { Accompaniment; } \\
\text { Sponsor; } \\
\text { Leadership; } \\
\text { Experience; }\end{array}$ & $\begin{array}{l}\text { Collaboration; } \\
\text { Vertical and } \\
\text { horizontal } \\
\text { participation; } \\
\text { Local and global } \\
\text { aspects }\end{array}$ & $\begin{array}{l}\text { Knowledge; } \\
\text { Experience; } \\
\text { Increase } \\
\text { collaboration; } \\
\text { Confidence in } \\
\text { collaboration }\end{array}$ & $\begin{array}{l}\text { Strengthening } \\
\text { community } \\
\text { interaction; } \\
\text { Creating new } \\
\text { patterns; } \\
\text { Solidarity local } \\
\text { wisdom }\end{array}$ \\
\hline
\end{tabular}

Source: (the results of data processing, 2018)

Based on some of the examples explain that social capital or community groups are an important part of state life because citizens do the best for the country through civic engagement. The collapse and revival of the American Community describe three important sources that exist in modern society, namely: 1) physical capital; 2) human capital; 3) social capital. Then, productivity can continue (Putnam, 2000). Developing community productivity requires welldesigned media and programs (Packham, 2008). Individuals must understand their existence or identity in social life. Thus, there is an adjustment to society in the social system with a focus on creating cooperative relationships.

\section{Discussion}

The first aim of organizing the Krakatau Festival was to promote the area and tourism potential in Lampung. Promotion carried out to attract a lot of tourist visits and spend their money at the festival place or in the city where it hosted and at the same time enjoying the festival. Mount Krakatau is very well-known in Indonesia and abroad, especially the fierce eruption of Mount Krakatau in 1883 until the dust from the eruption covered the earth for a long time. It lowered the earth's temperature by several degrees and occurred all over the earth including America to Europe. This historical value is very supportive in developing tourism in Lampung Province with the Krakatau icon.

The duty of the government and society nowadays is that the Krakatau Festival is not only successful in Indonesia but can also be included in the international tourist calendar. The Ministry of Tourism has to promote Krakatau on every travel map abroad. However, to enter the international calendar event, of course, it must have solid, creative human resources, and strong teamwork which is very important towards organizing internationally and becoming an international calendar event. The collaboration between the Lampung Provincial Tourism Office and various parties will strengthen steps to the successful of the Krakatau Festival.

In addition to placing other interesting supporting events, the Krakatau Festival will feature cultural parades from various regions in Lampung and cultures from outside Lampung as a 
tourist attraction. The Lampung elephant parade included in this parade and became a part of strengthening the Krakatau Festival icon as the flagship festival in Lampung Province. Original culture becomes a supporting reason to attract visitors and the public to see this festival first hand because something that has never been seen before can motivate visitors and tourists to take part. The original culture that has not been seen by many others and is then displayed here is Tuping. Tuping has its own historical story and message. An opportunity for visitors and the public to see the original culture displayed through the Krakatau Festival.

Another culture on the Krakatau Festival is the Tapis cloth parade. Tapis cloth is a woven cloth with a typical Lampung motif which is usually made with a mixture of gold thread, where the sarong or filter cloth is often worn during certain traditional events, weddings, and formal government events. The theme of Lampung Culture Tapis Carnival is very properly implemented in cultural parades. The cultural parade with the theme Tapis Carnival has experienced variations and creations adapted to today's modern era as reflected in costume performances.

Dreyfus and Dreyfus (1980) stated that the volunteer group model is comprehended from the level of skill and knowledge. According to Carol Packham, the model is still too simple and still needs to be linked to their involvement as volunteers in community groups. It is not only reflected from the experience and competence, but also from the volunteer to get involved and benefit himself, the community, and even the country. It is very possible to place volunteers on the spectrum of involvement in community groups and people. The government's efforts aim to bridge the relationship between voluntary activities and their engagement as active citizens. As it is known that in principle volunteering is to increase one's capacity to become better, prepare for the work done, and as a citizen in supporting community activities in particular. Storrie in Carol Packham (2008) stated that Volunteers who join together are a force (collective citizen) where they work together to form a solid team and form other patterns of cooperation. Therefore, as explained earlier that Carol Packham sees this as a reference and it must pay attention to other aspects such as 'in the work of state and civil society'.

The active participation of citizens has a strategic value in the current era of globalization. Every citizen can give in his active role through thoughts and ideas that are innovative, creative, and applicable. It is useful for the wider community. Festival is one form of citizen interaction that is very important to build and strengthen "social capital" in the social life of the community, nation, and state. Media such as festivals are maximally used to support the citizens' interaction from various cultures, occupations, different statuses at one time. With the various and varied forms of activities in a festival presented to the public, it is solely for uniting various groups of people to create good "engagement" with fellow citizens. Civic engagement is one of the steps to prepare the community by starting to become aware of personal identity and their existence as a community, to communicate more with people with different backgrounds, and to build bridges of understanding despite different cultures, races, education, and status. Thus, social relations in the life of a diverse society create strong social ties.

On the one hand, the community is waiting for their role in organizing the Krakatau Festival. The community involvement in question is official units, communities, volunteers, productive center groups, and creative economies such as handicrafts, food production, and clothing. The government in this case is the facilitator to prepare administration and a place for them to take part. Community involvement in the event explored in a study entitled Enchanting the Audience: Dramatic Devices of Sakura Mask Theater in West Lampung, Sumatra (Thomas, 2013). The results showed that the Sakura mask festival in West Lampung much involved the wider community. This involvement shown through dazzling and dynamic dance and music performances that get a very good response from the public with the charm that built up from this festival (Thomas, 2013). The Sakura mask festival involves hundreds of performers (parades, dancers) and thousands of spectators. 
Changes in various fields of life including social, political, and economic life today have provided opportunities for individuals, groups, and communities to play an active role in everyday life. Active citizens learn in society (community-based learning). People have contributed and goals achieved. Taking part in society, it means having developed two potentials simultaneously, namely the person potential and the potential strength of the community itself. Being actively involved at this time has brought people to join the community/group on a personal, local, global level, and get involved in other social activities (Packham, 2008).

Dynamic, fun, and warm interactions can grow through festival events. The current festival has become a medium that has its message from other forms of activity, because the full support of the government, stakeholders, and society, massively promotes and makes it a success (Lei \& Zhao, 2012; Adha et al., 2019). People want to be given space (Henderson \& Musgrave, 2014) where they can be creative and express themselves according to their abilities or skills (Funk et al., 2007; Havitz \& Dimanche, 1997). The stronger community support, the more characteristic values that exist in the festival maintained (De Bres \& Davis, 2001; Girish and Chen, 2017) and the message to be conveyed through the festival is well received by visitors and the community (Johansson \& Toraldo, 2015). A good reflection of an event is a sense of pride for organizers and community "civic pride" (Wood, 2006) to develop social capital (Arcodia \& Whitford, 2007), and it can also impact people by providing a sense of belonging and identity (De Bres \& Davis, 2001; Hixson, 2014).

There are several characteristics by open community groups, namely: "an open-minded and reflective approach, working from a firm foundation of values and assumptions, the ability to engage in a process of continuous review and professional inquiry" (Brechin et al., 2000). These characteristics become stronger with the support of democratic life as a way to listen to and respect the perspectives of others in social life (Cogan \& Derricot, 1998). Cooperation and participation of citizens is needed in the life of the nation and state, therefore the participation of people and communities in the process of social interaction serves to strengthen "social capital". In an established country, despite its democratic process, the focus is still on how to revitalize citizenship studies. The main study discussed is about the reduced level of citizen participation because it is related to social cohesion (Biesta \& Lawy, 2006; Lawy \& Biesta, 2006).

The freedom of expression, work, and creativity today has encouraged more and more participation from citizens in various fields of life. Therefore, the Indonesian people are becoming more critical and open to changes, especially those related to participating in various patterns of activities that show themselves as active citizens. In the conditions of social change in society as it is today. As active citizens, there will be sensitivities in themselves such as concern for the environment, cleanliness, information development, and a role in community activities. If we are working towards unity and collective action for change with groups, within which issues of power and hierarchy ignored, we are not likely successful (Ledwith, 2005, p. 162). Thus, the emphasis is on working together in society regardless of status or places, all participants are the same to make a change.

Citizens expected to have skills that can help in life and take part in various community activities effectively for the progress and welfare of society. Then citizens must also have the knowledge and skills needed in today's globalization era which is full of competition and very fast social changes. Therefore, the country is able to offer support and educate citizens to overcome various problems faced both as citizens, citizens of the community, and citizens of the world in order to survive, progress, and prosper.

\section{Conclusions}


Providing experiences for visitors and the community, it takes an organizing committee that arranges the event well, stakeholders, the visitors themselves, and the best participation from the community to create both physical change and social cohesion. Culture is always changing because of developed human knowledge, abilities and needs. Cultural changes caused by internal factors and can also be caused by external influences. Cultural and ethical creatures nothing but creatures always use their intellect to create happiness. In order to strengthening inter-cultural and inter-ethnic identity relations in society, of course, medium is needed so that community groups can come together that united through positive activities and build "social capital" that creates a sense of care and respect between people.

\section{Acknowledgment}

I wish to thank Lampung Krakatau Festival Committee from The Ministry of Tourism and Creative Economy, Lampung Province and all volunteers for support and insightful information to this research.

\section{Conflicts of Interest}

The author(s) declared no potential conflicts of interest with respect to the research, authorship, and/or publication of this article.

\section{References}

Adha, M.M. (2015). "Citizenship Education Optimizing Understanding of Cultural Differences of Indonesian Citizens in Studying the Manifestation of Pluralism in Globalization Era." Pendidikan Kewarganegaraan Mengoptimalisasikan Pemahaman Perbedaan Budaya Warga Masyarakat Indonesia Dalam Kajian Manifestasi Pluralisme Di Era Globalisasi. Jurnal Ilmiah Mimbar Demokrasi, 14 (2), 1-10.

Adha, M.M., Budimansyah, D., Sapriya., \& Sundawa, D. (2019). Emerging volunteerism for Indonesian millennial generation: Volunteer participation and responsibility Journal of Human Behavior in the Social Environment, 29 (4), 467-483.

Adha, M.M. (2019). Advantageous of Volunteerism Values for Indonesian Community and Neighbourhoods. International Journal of Community Service Learning, 3 (2), 83-87.

Arcodia, Charles \& Whitford, Michelle. (2006). "Festival Attendance and the Development of Social Capital." Journal of Convention \& Event Tourism, 8(2):1-18.

Biesta, Giesta \& Lawy, Robert. (2006). "From teaching citizenship to learning democracy: overcoming individualism in research, policy and practice." Cambridge Journal of Education, 36(1):63-79.

Brechin, Ann., Brown, Hilary., \& Eby, Maureen. A. (2000). Critical practice in health and social care. Sage Publications: London.

Bruveris, Klara. (2015). "Programming the Baltic Film Festival: delineating mainstream and community festivals." Studies in Australasian Cinema. 9(2):211-222.

Budimansyah, Dasim. \& Suryadi, Karim. (2008). "Citizenship and Multicultural Society". PKN dan Masyarakat Multikultural. Bandung: Civic education program UPI.

Chambel, Maria. J. \& Alcover, Carlos-Maria. (2011). "The psychological contract of call-centre workers: Employment conditions, satisfaction and civic virtue behaviours." Economic and Industrial Democracy, 32(1):115-134.

Chris, G. (2003). Tiger Tales-Programme 3-Indonesia. Retrieved Dec 3, 2016, from http://www.bbc.co.uk/radio4/history/tiger_tales/tiger_tales_indonesia.shtml.

Cogan, John. J, \& Derricot, Ray. (1998). Citizenship for the 21st Century, An International Perspective on Education. London: Kogan Page.

Cresswell. (2008). Educational Research: Planning, Conducting and Evaluating Quantitative and Qualitative Research Third Edition, New Jersey: Pearson Prentice Hall. 
De Bres, Karen. \& Davis, James. (2001). "Celebrating group and place identity: A case study of a new regional festival." Tourism Geographies, 3(3):326-337.

Doolittle, Amy. \& Faul, Anna. C. (2013). "Civic Engagement Scale: A Validation Study." Sage Open, 3(3): 1-7.

Einarsen, Kari \& Mykletun, Reidar J. (2009). "Exploring the Success of the Gladmat festival (The Stavanger Food Festival)." Scandinavian Journal of Hospitality and Tourism, 9(23):225-248.

Everett, Sally \& Parakoottathil, Denny. J. (2016). "Transformation, meaning making and identity creation through folklore tourism: the case of the Robin Hood Festival." Journal of Heritage Tourism, 13(1):35-40.

Fahm, Abdulgafar. O. (2015). Ijebu Ode's Ojude Oba Festival: Cultural and Spiritual Significance. SAGE Open, 5(1):1-11.

Felsenstein, Daniel., \& Fleischer, Aliza. (2003). "Local festivals and tourism promotion: the role of public assistance and visitor expenditure." Journal of Travel Research, 41(4):385-392.

Formica, Sandro., \& Uysal, Muzaffer. (1998). "Market segmentation on an international cultural-historical event in Italy." Journal of Travel Research, 36(4):16-24.

Frost, Nicola. (2016). "Anthropology and Festivals: Festival Ecologies." Ethnos, 81(4):569-583.

Funk, Daniel. C. \& Bruun, Tennille. J. (2007). "The role of socio-psychological and cultureeducation motives in marketing international sport tourism: A cross-cultural perspective." Tourism Management, 28(3):806-819.

Gibson, Chris., Waitt, Gordon., Walmsley, Jim., \& Connell, John. (2010). "Cultural Festivals and Economic Development in Nonmetropolitan Australia." Journal of Planning Education and Research, 29(3):280 -293.

Girish, V. G. \& Chen, Ching-Fu. (2017). "Authenticity, experience, and loyalty in the festival context: Evidence from the San Fermin festival, Spain." Current Issues in Tourism, 20(15): 1551-1556.

Gursoy, Dogan., \& Rutherford, Denney. G. (2004). "Host attitudes toward tourism: An improved structural model." Annals of Tourism Research, 31(3):495-516.

Havitz, Mark. E. \& Dimanche, Frederic. (1997). "Leisure Involvement Revisited: Conceptual Conundrums and Measurement Advances." Journal of Leisure Research, 29(3):245-278.

Henderson, Stephen. \& Musgrave, James. (2014). "Changing audience behaviour: festival goers and throwaway tents." International Journal of Event and Festival Management, $5(3): 247-262$.

Hixson, Eliza. (2014). "The impact of young people's participation in events." International Journal of Event and Festival Management, 5(3):198 - 218.

Lee, Tain-Shyug., Huh, Chung. L., Yeh, Hung-Ming \& Tsaur, Wei-Guang. (2016). "Effectiveness of a communication model in city branding using events." International Journal of Event and Festival Management, 7(2):137-148.

Matheson, Chaterine. M. \& Tinsley, Ross. (2016). "The carnivalesque and event evolution: a study of the Beltane Fire Festival." Leisure Studies, 35(1): 1-27.

Meiliyana., Ma'arif, S., \& Meilinda, S.D. (2020). Stakeholder Partnership in the Management of Marine Tourism in South Lampung Regency, Lampung. Indonesian Journal of Tourism and Leisure, Vol. 01 (2), 82-91

Packham, Carol. (2008). Active Citizenship and Community Learning. United Kingdom: Learning Matters.

Pardy, S. G. (1991). A study of the role of community festivals and events in community development. Unpublished master's thesis, USA: Acadia University. 
Pizam, A., \& Milman, A. (1986). "The social impacts of tourism." Tourism Recreation Research, 11:29-32.

Gursoy, Dogan., Jurowski, Claudia., \& Uysal, Muzaffer. (2002). "Resident attitudes: A structural modeling approach." Annals of Tourism Research, 29(1):79-105.

Johansson, Marjana \& Toraldo, Maria. L. (2001). "From mosh pit to posh pit: Festival imagery in the context of the boutique festival." Culture and Organization, 23(3):220-237.

Kim, Dohee., Lee, Choong-Ki \& Sirgy, M. Joseph. (2016). "Examining the Differential Impact of Human Crowding Versus Spatial Crowding on Visitor Satisfaction at a Festival." Journal of Travel \& Tourism Marketing, 33(3):293-312.

Lawy, Robert \& Biesta, Gert. (2006). "Citizenship-as-practice: the educational implications of an inclusive and relational understanding of citizenship." British journal of educational studies, 54(1):34-50.

Lankford, Samuel. V. (1994). "Attitudes and perceptions toward tourism and rural regional development." Journal of Travel Research, 24(3):35-44.

Lei, Wengsi. dan Zhao, Weibing. (2012). "Determinants of arts festival participation: an investigation of macao residents." Event Management, 16(4):283-294.

Müller, Dieter. K \& Petterson, Robert. (2006). "Sámi Heritage at the Winter Festival in Jokkmokk, Sweden." Journal Scandinavian Journal of Hospitality and Tourism, 6(1):5469 .

Persada, Citra. (2011). "Tourism in Regional Planning (Building Lampung as a New Destination Pariwisata Dalam Perencanaan Wilayah (Membangun Lampung sebagai Destinasi Baru). Department of Civil Engineering, Faculty of Engineering, University of Lampung: Lampung.

Putnam, Robert. D. (2000). Bowling Alone: The Collapse and Revival of American Community. New York: Simon and Schuster.

Rao, V. (2001). "Celebrations as Social Investments: Festival Expenditures, Unit Price Variation and Social Status in Rural India." Journal of Development Studies, 38(1):71-97.

Roemer, Michael. K. (2010). "Shinto festival involvement and sense of self in contemporary Japan.” Japan Forum, 22(3-4):491-512.

Sandu, Oana. N. (2015). "Civic and Intercultural Education, A Means for Community Development and Attitude Change." SAGE and Open Access, 5(2).

Stone, Clarence. N. (2001). "Civic Capacity and Urban Education." Urban Affairs Review, 36(5):595-619.

Supriono. (2017). "Analysis of the description of the tourism potential of Batam City to attract foreign tourists". Analisis deskripsi potensi pariwisata Kota Batam dalam rangka menjaring wisatawan mancanegara. Jurnal Pariwisata Terapan, 1(2):97-106.

Supriyono \& Adha, M.M. (2020). "Building Leadership Based on Pancasila in the Perspective of a Multicultural Society”. Membangun Kepemimpinan Berbasis Nilai-Nilai Pancasila Dalam Perspektif Masyarakat Multikultural. Jurnal Kultur Demokrasi, 9 (2), 1-10.

Van Der Wagen, L., \& Carlos, B. R. (2005). Event management for tourism, cultural, business and sporting events. Upper addle River, NJ: Prentice Hall.

Kemenpar. (2018). 100 wonderful events Indonesia 2018. Retrieved April 25, 2018, from www.kemenpar.go.id/final.pdf.

Long, Patrick. T., \& Perdue, Richard. R. (1990). "The Economic Impact of Rural Festivals and Special Events: Assessing the Special Distribution of Expenditures." Journal of Travel Research, 28(4):10-14.

Sommers, Laurie. K. (1996). "Definitions of "Folk" and "Lore" in the Smithsonian Festival of American Folklife." Journal of Folklore Research, 33(3):227-231. 
Thomas, Karen. K. (2013). "Enchanting the Audience: Dramatic Devices of Sakura Mask Theatre in West Lampung, Sumatra." Asian Theatre Journal, 30(2), University of Hawai'i Press: Honolulu.

Van Zyl, C. \& Botha, Christel. (2004). 'Motivational factors of local residents to attend the Aardklop National Arts Festival.' Event Management, 8(4):213-222.

Wibowo, Tangguh, O. (2018). "Strategy for Developing Lasem City's Attractiveness as a BatikCoffee City". "Strategi Pengembangan Daya Tarik Kota Lasem Sebagai Kota Batik-Kopi." Jurnal PariwisataTerapan, 2(1):1-13.

Wood, Emma. H. (2006). "Measuring the social impacts of local authority events: a pilot study for a civic pride scale." International Journal of Nonprofit and Voluntary Sector Marketing, 11(3):165-179.

Woosnam, Kyle. M. \& Aleshinloye, Kayode. D. (2015). "Residents' emotional solidarity with tourists: explaining perceived impacts of a cultural heritage festival." Journal of Hospitality \& Tourism Research, XX(X):1-19. 